\section{Observation of Bryde's Whale Balanoptera edeni / brydei (Cetartiodactyla: Balaenoptiidae) in the offshore waters of southern Odisha, eastern India}

\author{
Sajan John ${ }^{1}$, K. Sivakumar ${ }^{2}$, B.C. Choudhury ${ }^{3}$ \\ \& Muntaz Khan ${ }^{4}$ \\ 1,2,3 Wildlife Institute of India, Post Box \# 18, Chandrabani, \\ Dehradun, Uttarakhand 248001, India \\ ${ }^{4}$ Research scholar, Chilika Development Authority, Plot No. \\ C-11, BJB Nagar, Bhubaneswar, Odisha 751014, India \\ 1 Present address: Dakshin Foundation, Sahakaranagar, \\ Bengaluru, Karnataka 560092, India \\ Email: ${ }^{1}$ sajanjohn09@gmail.com (corresponding author), \\ 2ksivakumar@wii.gov.in, ${ }^{3}$ bcc@wii.gov.in, ${ }^{4}$ soneyal@yahoo. \\ co.in
}

Balanoptera edeni / brydei (Anderson, 1879 / Olsen, 1913) is a widely distributed rorqual (Reilly et al. 2008) that inhabits tropical waters and does not perform extensive migrations to high latitude feeding grounds like other whales in the genus (Best 2001). The taxonomy of the genus is uncertain due to the similar appearance of two generally recognised forms which are almost certainly separate species, $B$. edeni and $B$. brydei (Wada et al. 2003). The International Union for Conservation of Nature (IUCN) lists this species as

Date of publication (online): 26 August 2012

Date of publication (print): 26 August 2012

ISSN 0974-7907 (online) | 0974-7893 (print)

Editor: Brian Smith

Manuscript details:

Ms \# 02732

Received 19 March 201

Final received 16 May 2012

Finally accepted 25 July 2012

Citation: John, S., K. Sivakumar, B.C. Choudhury \& M. Khan (2012) Observation of Bryde's Whale Balanoptera edeni / brydei (Cetartiodactyla: Balaenoptiidae) in the offshore waters of southern Odisha, eastern India. Journal of Threatened Taxa 4(9): 2924-2927.

Copyright: ( ) Sajan John, K. Sivakumar, B. C. Choudhury \& Muntaz Khan 2012. Creative Commons Attribution 3.0 Unported License. JoTT allows unrestricted use of this article in any medium for non-profit purposes, reproduction and distribution by providing adequate credit to the authors and the source of publication.

Acknowledgements: We thank The Directorate General of HydrocarbonWildlife Institute of India (DGH-WII) Marine turtle tracking project for logistics and support, Anouk Ilangakoon and Elisabeth Mansur for valuable suggestions, annonymous reviewers for their comments and field staff in Rushikulya, Odisha for their assistance.

OPEN ACCESS | FREE DOWNLOAD
Data Deficient (Reilly et al. 2008) but it is included in Appendix I of Conservation of International

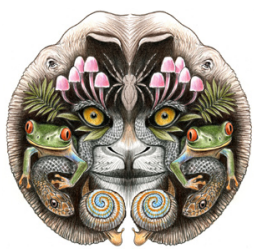
Trade of Endangered Species of Flora and Fauna (CITES) and listed in Appendix II of Convention on Migratory Species (CMS).

Bryde's Whales are widely distributed in the Indian Ocean; however, records in Indian waters are rare (Sathasivam 2004) and largely based on strandings. On 22 May 2009, around 09:35 (IST) three whales (two adults and one probable juvenile) were sighted $6 \mathrm{~km}$ offshore $\left(19^{\circ} 16^{\prime} 42.43 \mathrm{~N} \& 85^{\circ} 02^{\prime} 46.87 \mathrm{E}\right)$, at a depth of 28-32 m, south of Rushikulya River mouth, southern Odisha (Image 1). All three whales were heading north along the coast at about $3.5 \mathrm{~km} / \mathrm{hr}$. No indications of feeding were observed. The lengths of the adult whales were estimated to be $11-13 \mathrm{~m}$ and the probable juvenile $8-10 \mathrm{~m}$ based on their size relative to our $7 \mathrm{~m}$ long boat.

The whales were identified as Bryde's Whales (Balanoptera edeni / brydei) based on the prominent lateral ridges located on each side of the median ridge on the head of the two adult whales and their pointed falcate dorsal fin (Cummings 1985). The irregular rolling pattern of the smaller whale did not allow us to observe its head region. The smaller whale was slightly paler in contrast to the adults and its dorsal fin was more falcate.

The whales were cruising through the water and approached the boat as close as $2 \mathrm{~m}$. The surfacing sequence was captured using a digital still camera (Image 2). The whale did not lift its flukes when diving. Three whales, which were sighted earlier in the same region during April 2009 (by the first author), had similar dorsal fins and rolling patterns; it is uncertain whether or not these were the same individuals.

Bryde's Whales are the only non-migratory species of Baleen Whale. They are found in the tropics and sub-tropics (Barlow 2006). The nearest known Bryde's Whale population from the Odisha coast is $500 \mathrm{~km}$ north in the Bangladesh region of the Swatchof-No-Ground (SoNG) submarine canyon (Smith et al. 2008). Genetic evidence from the MtDNA control region of 38 tissue samples from Bryde's Whales in the SoNG indicates the presence of the small edeni form; however, the same analysis also included a single tissue sample of a Bryde's Whale that stranded 


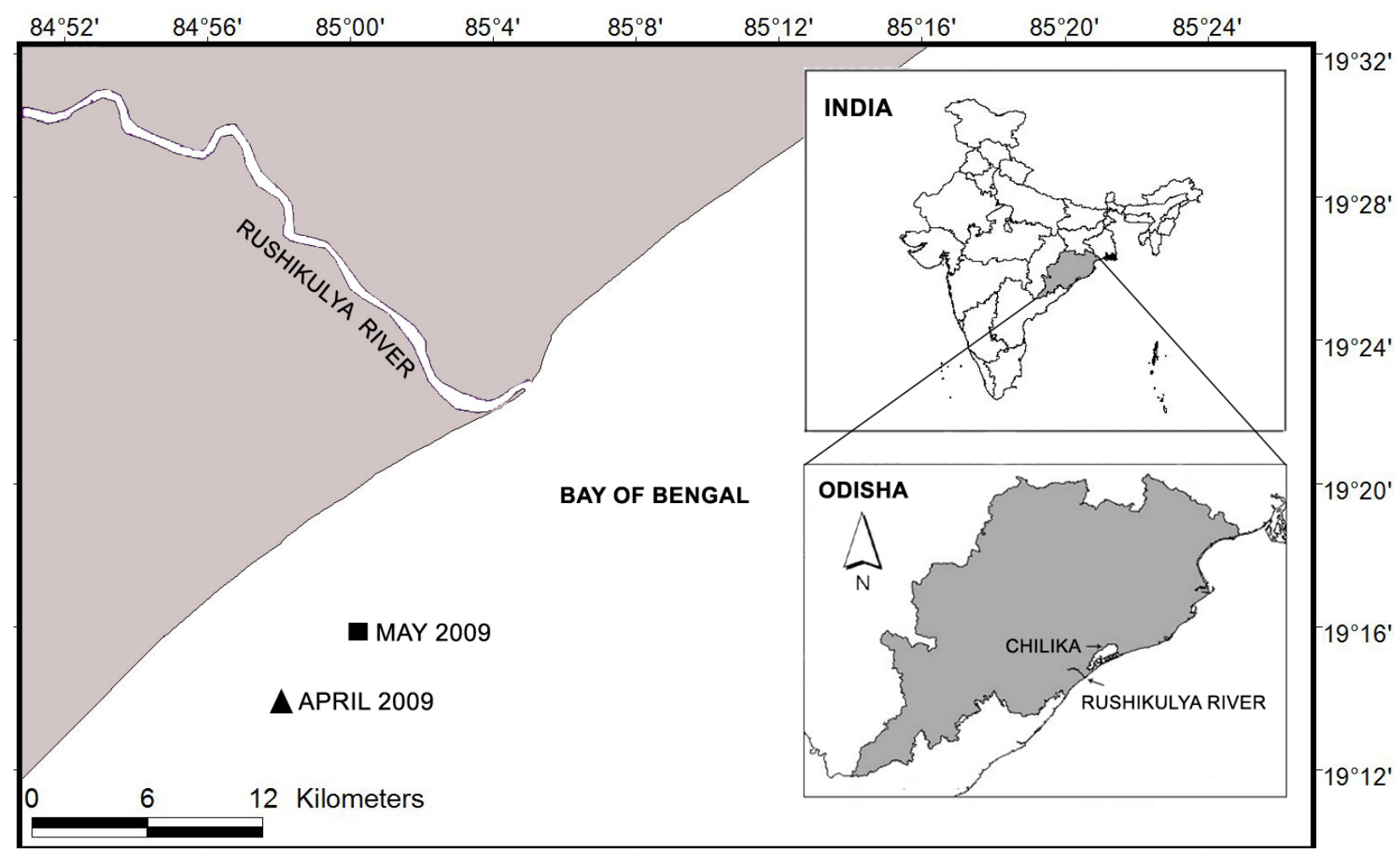

Image 1. Map of the Odisha coast showing the Rushikulya River and whale sighting locations.

near Cox's Bazaar which was found to be from the large brydei form. So there is at least some degree of sympatry between the two incipient species in the Bay of Bengal (Smith B.D, pers. comm. 29 May 2011).

A stranded Bryde's Whale from Gulf of Mannar (south-east coast of India) was identified as B. edeni based on genetic evidence from MtDNA (Jayasankar et al. 2009). Another stranded Bryde's Whale from Thiruvananthapuram coast (southwest coast of India) also was genetically identified as $B$. edeni based on DNA sequences of mitochondrial cytochrome oxidase subunit I (COI) gene (George et al. 2011). These records are the only published information till date that have used genetic materials to confirm that the Bryde's Whale from Indian waters are the edeni form.

Odisha has a rich cetacean diversity. A total of 14 cetacean species [Minke Whale Balaenoptera acutorostrata, Sei Whale Balaenoptera borealis, Bryde's Whale Balanoptera edeni / brydei, Sperm Whale Physeter macrocephalus, False Killer Whale Pseudorca crassidens, Ganges River Dolphin Platanista gangetica gangetica, Irrawaddy Dolphin Orcaella brevirostris, Bottlenose Dolphin Tursiops aduncus / trancatus, Indo-Pacific Humpback Dolphin Sousa chinensis, Spinner Dolphin Stenella longirostris, Striped Dolphin Stenella coeruleoalba, Risso's Dolphin Grampus griseus, Finless Porpoise Neophocaena phocaenoides phocaenoides, Common Dolphin Delphinus delphis] have been recorded from the coastal and inland waters of Odisha (James et al. 1989; Jayaprakash et al. 1995; M. Khan pers. comm. 2010). Till date, only seven published documents are available on the occurrence of Bryde's Whale from Indian waters (Table 1). Of these, only one was a live sighting (Leatherwood 1984) and the rest were stranding records. The lack of systematic offshore cetacean monitoring might be a reason for this.

Photo-identification of distinctive marks from Bryde's Whales in the Indian region of Bay of Bengal could inform us whether the species migrates from SoNG or if a separate population exists in the Indian region of the Bay of Bengal. Molecular studies can also unravel the taxonomic complexities associated with these species.

All marine mammals are given priority under "Schedule I" of the Indian Wildlife (Protection) Act, 1972 (Anon 2003). There are no targeted fisheries for marine cetaceans in India. Possible threats to marine mammals are from ongoing and proposed off-shore development activities. In the near future, major 

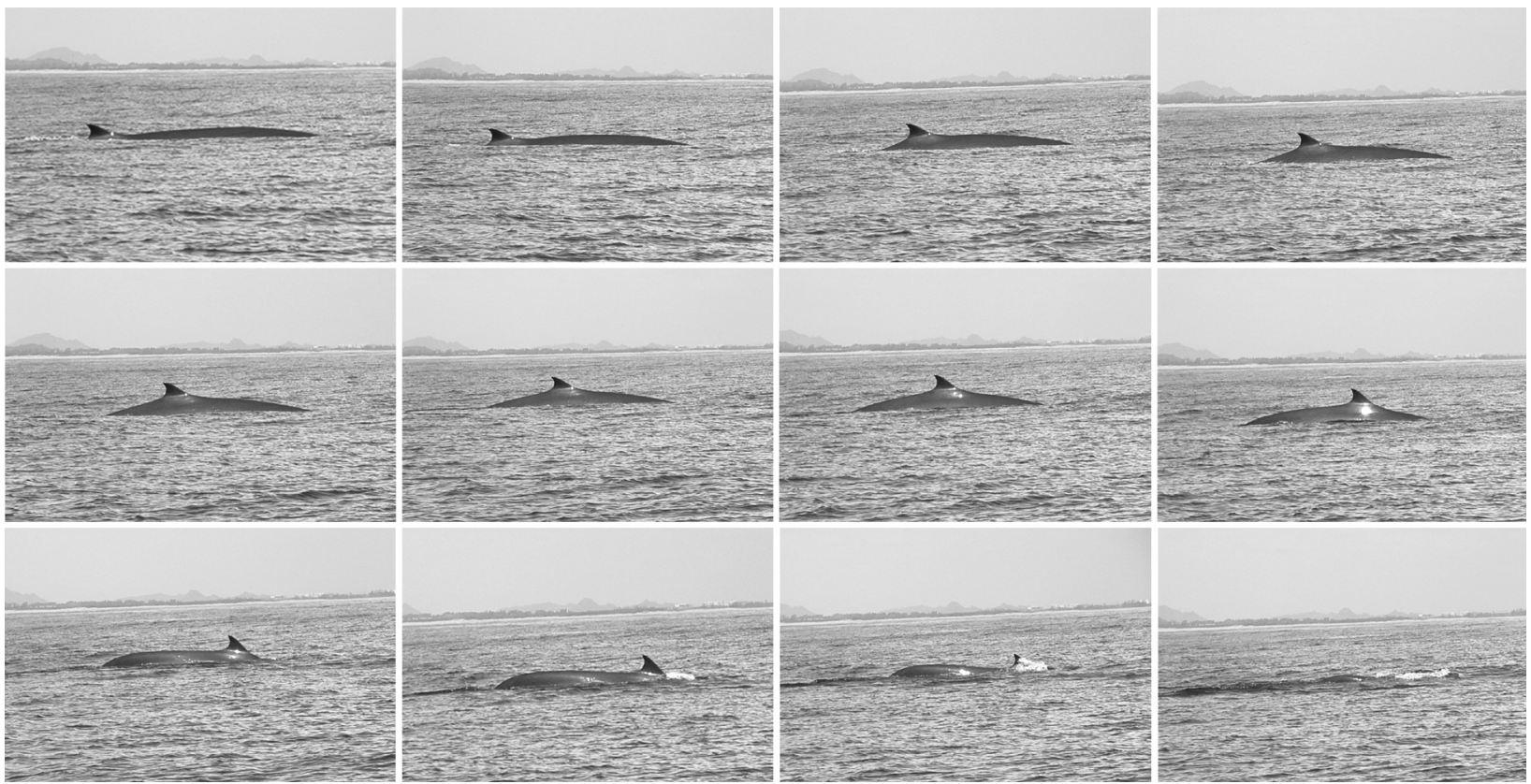

Image 2. Complete rolling sequence of the adult whale before diving sighted during May 2009. @ Sajan John

hydrocarbon exploration is planned for the offshore waters of Odisha (Pannu 2005). Oil exploration activities may impact pelagic and coastal marine mammals. Noise pollution from oil and gas exploration and increased vessel traffic can have negative impacts on cetaceans (Wyrick 1954; Bogoslovskaya et al. 1981; Malme et al. 1989). Oil itself can also cause cetacean mortality and adversely affect the fish and invertebrates on which the cetaceans feed (Ridoux et al. 2004).

Within a single year, the Odisha coast has witnessed two oil spills: from MV Black Rose near Paradip port (Pattnaik 2009) and the oil slick of MV Malavika, near Gopalpur Port (Reddy 2010). How these offshore development activities and marine pollution will affect the cetaceans along the Odisha coast needs further investigation and management interventions.

\section{REFERENCES}

Anonymous (2003). The Wildlife Protection Act, 1972, pp.149163. Wildlife Trust of India. Natraj, Dehradun, India.

Barlow, J. (2006). Cetacean abundance in Hawaiian waters estimated from a summer/fall survey in 2002. Marine Mammal Science 22 (2): 446-464.

Best, P.B. (2001). Distribution and population separation of Bryde's whale Balaenoptera edeni off southern Africa Marine Ecology Progress Series 220: 277-289.

Bogoslovskaya, L.S., L.M. Votrogov \& T.N. Semenova
(1981). Feeding habits of the gray whale off Chukotka. Report of the International Whaling Commission 31: $507-$ 510.

Cummings, W.C. (1985). Bryde's Whale Balaenoptera edeni Anderson, 1878, pp.137-154. In: Ridgway. S.H. \& R.J. Harrison (eds.). Handbook of Marine Mammals, Vol. 3: The Sirenians and Baleen Whales. Academic Press, London, UK, 362pp.

De Silva, P.H.D.H. (1987). Cetaceans whales, dolphins and porpoises recorded off Sri Lanka, India, from the Arabian Sea and Gulf, Gulf of Aden and from the Red Sea. Journal of the Bombay Natural History Society 84(3): 505-525.

George, S., K. Meenkashi \& A. Bijukumar (2011). Molecular taxonomy of marine mammals stranded along Kerala coast, India. Current Science 100(1): 117-120.

James, P.S.B.R., M. Rajagopalan, S.S. Dan, A. Bastian Fernando \& V. Selvaraj (1989). On the mortality and stranding of marine mammals and turtles at Gahirmatha, Orissa from 1983 to 1987. Journal of the Marine Biological Association of India 31(1): 28-35.

Jayaprakash, A.A., P. Nammalwar, S.K. Pillai \& M.N.K. Elayath (1995). Incidental by catch of dolphins at Fisheries Harbour, Cochin, with a note on their conservation and management in India. Journal of the Marine Biological Association of India 37(1\&2): 126-133.

Jayasankar, P., B. Anoop, V.V. Afsal \& M. Rajagopalan (2006). Species and sex of two baleen whales identified from their skin tissues using molecular approach. Marine Fisheries Information Service 190: 16-17.

Jayasankar, P., B. Anoop, M. Rajagopalan, K.M.M. Yousuf, P. Reynold, P.K. Krishnakumar, V.V. Afsal \& A.A. Krishnan (2009). Indian efforts on the inventorization of marine mammal species for their conservation and 
Table 1. Sighting and stranding records of Bryde's Whale from Indian waters chronologically.

\begin{tabular}{|c|c|c|c|}
\hline & Date & Details & References \\
\hline 1 & ??? & Recorded from Bay of Bengal By Blanford & De Silva,1987 * \\
\hline 2 & 02 Jul 1979 & $13 \mathrm{~m}$ male stranded Near Calicut, west coast of India & Lal Mohan, 1992 \\
\hline 3 & 20 Feb 1983 & Seven of these whales seen on cruise from Madras to Trincomalee & Leatherwood, 1984 * \\
\hline 4 & 20 Feb 1983 & $13.52 \mathrm{~m}$ stranded specimen from Gulf of Mannar, east coast of India & Lal Mohan, 1992 \\
\hline 5 & 14 Nov 2000 & $12 \mathrm{~m}$ stranded specimen from Point Calimere, east coast of India & Sathasivam, 2002 \\
\hline 6 & 08 Aug 2006 & $12 \mathrm{~m}$ male stranded near Mandapam at gulf of Mannar, East coast of India & Jayasankar et al. 2006 \\
\hline 7 & 23 May 2007 & $12 \mathrm{~m}$ stranded specimen from south of Rushikulya River, Odisha, East coast of India & M. Khan pers. obs. April 2009 \\
\hline 8 & 22 May 2009 & Three, live whales sighted off Odisha coast & Present report \\
\hline 9 & 29 July 2010 & $\begin{array}{l}\text { 15.7m stranded specimen from south of Rushikulya River, Near Gopalpur light house, } \\
\text { Odisha, East coast of India. Skeleton preserved at RMNH, Bhubaneshwar }\end{array}$ & $\begin{array}{l}\text { Dr. Siba Prasad Parida pers. } \\
\text { obs. July } 2010\end{array}$ \\
\hline 10 & 27 Jun 2009 & $3.9 \mathrm{~m}$ stranded specimen from Trivandrum District, Kerala, south west coast of India & George et al. 2011 \\
\hline
\end{tabular}

* Source of the reference - K. Sathasivan 2004

management. Asian Fisheries Science 22: 143-155.

Mohan, R.S.L.(1992). Observations on the whales Balaenoptera edeni, B. musculus and Megaptera novaeangliae washed ashore along the Indian coast with a note on their osteology. Journal of the Marine Biological Association of India 34(1\&2): 253-255.

Leatherwood, S. (1984). Further notes on cetaceans of Sri Lanka. Paper No.SC/36/06 presented to the International Whaling Commission Scientific Committee, 12pp.

Malme, C.I., P.R. Miles, G.W. Miller, W.J. Richardson, D.G. Roseneau, D.H. Thomson \& C.R. Greene (1989). Analysis and ranking of the acoustic disturbance potential of petroleum industry activities and other sources of noise in the environment of marine mammals in Alaska. Final report No. 6945 to the US minerals management service, Anchorage, AK. BBN systems and Technologies Corporation. Downloaded from $<$ http://www.gomr.boemre. gov/PI/PDFImages/ESPIS/0/134.pdf $>$ Downloaded on 30 September 2011

Pannu, S.P.S. (2005). Shackles off oil hunt on Orissa coast. Downloaded from: < http://www.telegraphindia. com/1051204/asp/business/story_5556834.asp > Downloaded on 17 October 2010

Pattnaik, S. (2009). Oil spill: clean-up will cost crores. Downloaded from: <http:/www.hindustantimes.com/Oilspill-Clean-up-will-cost-crores/Articles-456992.aspx> Downloaded on 17 October 2010

Reddy, M.V. (2010). Threat of Gopalpur port oil spill to Olive Ridley Turtles and their hatchlings. Current Science 99(3): $267-268$.
Reilly, S.B., J.L.Bannister, P.B. Best, M. Brown, R.L. Brownell Jr., D.S. Butterworth, P.J. Clapham, J. Cooke, G.P. Donovan, J. Urbán \& A.N. Zerbini (2008). Balaenoptera edeni. In: IUCN 2010. IUCN Red List of Threatened Species. Version 2010.3. <www.iucnredlist. org $>$. Downloaded on 18 October 2010

Ridoux, V., L. Lafontaine, P. Bustamante, F.Caurant, W. Dabin, C. Delcroix, S. Hassani, L. Meynier, Da Silva V. P, S. Simonin, M. Robert, J. Spitz \& O. Canneyt (2004). The impact of the "Erika" oil spill on pelagic and coastal marine mammals: Combining demographic, ecological, trace metals and biomarker evidences. Aquatic Living Resources 17: 379-387.

Sathasivam, K. (2002). Two whale records from Tamil Nadu, southern India. Journal of the Bombay Natural History Society 99(2): 289-290.

Sathasivam, K. (2004). Marine Mammals of India. University Press, Hyderabad, xxiii+184pp.

Smith, B.D., B. Ahmed, R.M. Mowgli \& S. Strindberg (2008). Species occurrence and distributional ecology of nearshore cetaceans in the Bay of Bengal, Bangladesh, with abundance estimates for Irrawaddy dolphins Orcaella brevirostris and finless porpoise Neophocaena phocaenoides. Journal of Cetacean Research and Management 10(1): 45-58.

Wada, S., M. Oishi, \& T.K. Yamada (2003). A newly discovered species of living Baleen Whale. Nature 426: 278-281.

Wyrick, R.F. (1954). Observations on the movements of the Pacific Gray Whale Eschrichtius glaucus (Cope). Journal of Mammalogy 35(4): 596-598. 